$\begin{array}{lllllllllll}S & E & M & \text { I } & \text { H } & \text { A } & \mathbb{R} & \mathbb{R} & 0 & 0 & M\end{array}$

\title{
深海微生物に期待!
}

\section{秦田勇二, 宮崎征行，大田ゆかり}

海洋研究開発機構海洋 ·極限環境生物圏領域

はじめに

地球表面の 7 割は海洋が占め, さらに, 海洋の平均深 度は3,800 mであり, 海洋は莫大な体積（生命保持領 域）を抱えていると言える. 地球上の炭素の分配を見て も海洋中に含まれる炭素比率は陸上と比較して 17 倍多 いと計算される．生物は海洋から発生し進化を続け, 多 様性を創り上げてきた。したがって，海洋には数限りな い種類の生体触媒が存在している。 それらの生体触媒か ら，人々の生活を豊かにする生体触媒（酵素など）を探 し出すことに大きな可能性と使命を感じる，墚海は暗 闇，低温 $\left(4^{\circ} \mathrm{C}\right.$ 前後）で高水圧の環境である. 20 世紀後 半以降の潜水艇の開発に伴い深海の様子が少しずつ明ら かになってきた（しかしいまだわからないことだらけの 謎の世界である)、筆者らが所属する海洋研究開発機構 では有人潜水調査船（図1）や深海探査機などを用いて 深海の謎の解明に挑んでおり, 深海調査成果の一つとし て, 深海領域は微生物に関しても多大な新規性と多様性 に満ちていることがわかってきた，筆者らはバイオリ ソースとして大きな可能性を秘めている深海微生物を対 象に新規有用酵素の探索を試みている。そののいつかの 取り組みを紹介させていただく。
深海底泥からのアガラーゼ生産菌のスクリーニング

日本人が古くから食材として利用している寒天は紅藻 類に属する海藻（テングサ, オゴノリなど）から抽出さ れる. その主成分はアガロースと呼ばれる多糖であり, D-ガラクトースと 3,6-アンヒドロ-L-ガラクトースが $\alpha-1,3$, $\beta-1,4$ 結合で交互につながった面白い構造をしている. アガロースを切断して得られるオリゴ糖には制がん効果 や美白効果などの生理機能活性があることが報告されて いる．そこで筆者らはアガロースをオリゴ糖サイズに切 断する酵素「アガラーゼ」を生産する微生物を, 深海底

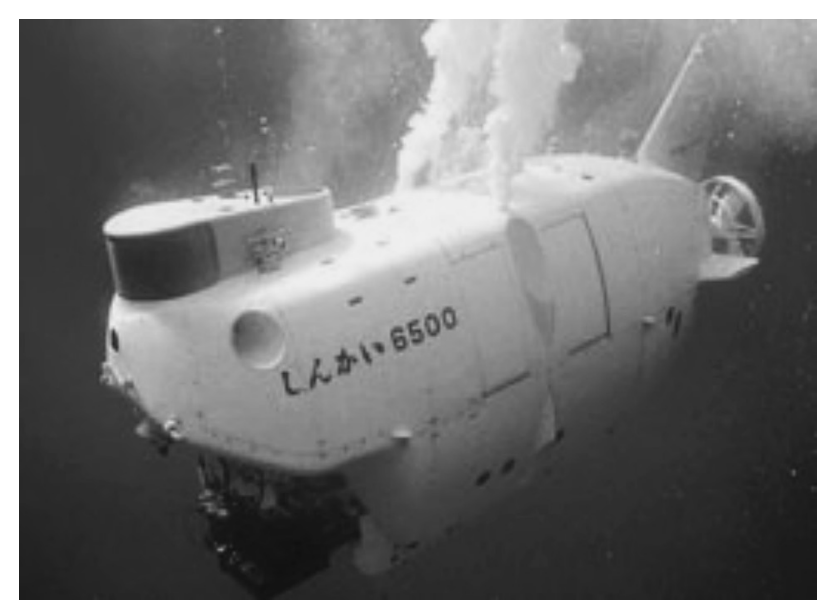

図 1 - 有人潜水調查船「しんかい6500」 


\section{連載開始にあたって : 海洋生物資源への期待 : マリンバイオテクノロジーの現場から}

海洋は, 地球の表面積の約 7 割を占め, 平均深度は $3,800 \mathrm{~m}$ にも達する. そこには熱水噴出孔や寒冷な極地, 高水圧の深海などさまざまな環境に適応した多種多様な能 力をもった生物が存在する. 生物がエネルギー代謝として 酸素発生を伴う光合成を獲得したのは約 27 億年前であり, 光合成する生物, 藻類（シアノバクテリア）により大気中 の酸素濃度が増加し, 今の地球環境の礎ができあがった. このような多様な環境を有する海洋の生物資源は, 古くか ら私たちの生活を食だけでなく医薬品を通じた健康という 面からも支えてきた．近年では海洋藻類をバイオマスとし たエネルギー生産も期待されている。一方，有用物質を生 産する微生物が必ずしも人工的な環境で培養できるとは限 らず，分離，培養可能な微生物は $1 \%$ に満たないと言わ れている，海洋は有用微生物の宝庫であり，培養ができな い微生物についても資源として利用できれば，新たな医薬 品開発やエネルギー生産への道が広がると期待される.

本シリーズ「海洋生物資源への期待：マリンバイオテク ノロジーの現場から」では, 海洋利用研究のさまざまな取 り組みについて海洋生物資源に焦点をあてながら 5 回にわ たって紹介していただく、シリーズ第 1 回，秦田勇二先生 ら (海洋研究開発機構) は，日本が世界をリードする深海 研究における生物資源に関して解説していただき，第 2 回
目は田中 剛先生ら（東京農工大・工）によって，自然工 ネルギーとして現在産官学一体として取り組みが進められ ているバイオ燃料生産について，海洋微細藻類をバイオマ ス資源とした最新の研究について紹介していただく。第 3 回目は，家戸敬太郎先生ら（近畿大・水産）に，マグロ完 全養殖を通じて, 日本の最先端養殖技術について紹介して いただく、第 4 回目は, 高田健太郎先生ら（東京大院・ 農）に創薬研究に大きな貢献が期待されている海洋天然物 の探索と応用について紹介していただく、最後に，竹山 (早稲田大・生命医科) が，海洋の難培養微生物の有効活 用をゲノム情報に基づいて進めるメタゲノム研究について 報告し，本シリーズを完了する。

日本は国土を海洋に囲まれた海洋国家であり，排他的経 済水域 (exclusive economic zone;EEZ) は世界第6位の 広さである。このような海洋をいかに有効利用するかは, 今後の日本の発展に大きく影響するものである. 2007 年 4 月に海洋基本法が成立したが，海洋資源開発はその施策の 重要項目である．多くの研究者が，精力的にこの分野で活 躍しており，その一端を本シリーズで紹介することで，新 たなネットワークができることを期待している.

(竹山春子, 早稲田大学先進理工学部生命医科学科)
泥サンプルを対象に探索したわずかな炭素源と人工海 水を主成分とする寒天固体培地上に，深海底泥サンプル を人工海水で希釈した溶液を塗布して数日間保温した $\left(4^{\circ} \mathrm{C}, 15^{\circ} \mathrm{C}, 37^{\circ} \mathrm{C}\right.$ の各温度にて) 結果, 出現した数多く の微生物のコロニーに交じってまれにコロニー周囲に凹 みを形成する微生物が見受けられた。それらの微生物の うちのいくつかを選択して $16 \mathrm{~S}$ rRNA 遺伝子の配列解析 を行った結果, Agarivorans属, Microbulbifer属, Pseudoalteromonas属, Shewanella属, Thalassomonas

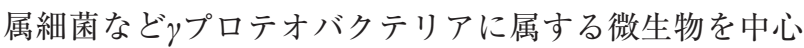
に予想以上に多くの微生物種のアガラーゼ生産菌が取得 された。

\section{アガラーゼ生産菌A94株}

深海底泥サンプル由来アガラーゼ生産菌のなかから本 項ではA94株を紹介する（図2）。本微生物は駿河湾の 深度 $2,406 \mathrm{~m}$ に位置する深海底泥サンプルより発見され た。系統解析の結果, A94株はMicrobulbifer属細菌の 仲間であり， $52^{\circ} \mathrm{C}$ という高温でも生育できるその特徵か ら Microbulbifer thermotolerans と命名した ${ }^{(1)}$. 本微生
物のゲノムDNAを対象に，ショットガンクローニング 法によりアガラーゼをコードする遺伝子を探索した結 果， GH (Glycoside hydrolase) ファミリー16に属する $\beta$ アガラーゼ (AgaA) 遺伝子 (ORF ; 1299 bp) と GHファ ミリー 86 に属する $\beta$ アガラーゼ $(\mathrm{AgaO})$ 遺伝子 （ORF；3528 bp）の2種の遺伝子が取得された．つづい て，枯草菌を宿主として各々の酵素遺伝子を発現させた 後，各組換え酵素の諸性質を調べたところ，AgaAと
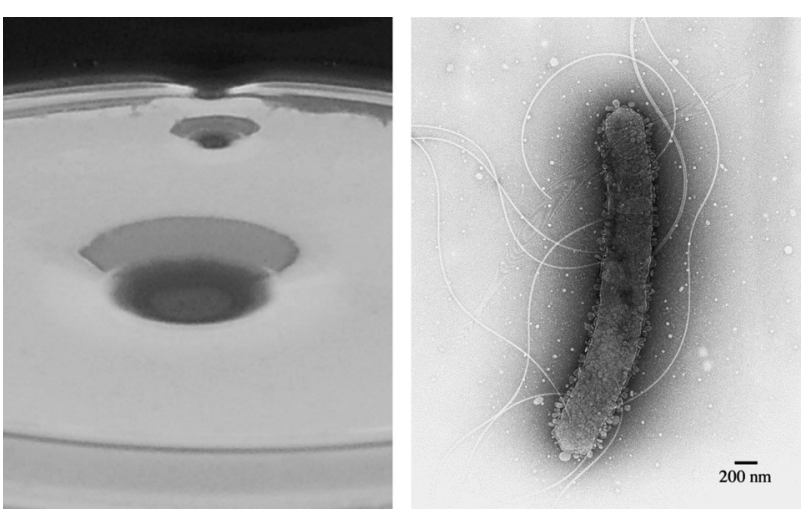

図 2 A94株の寒天固体培地上での生育の写真(左)と電顕写真 (右) 


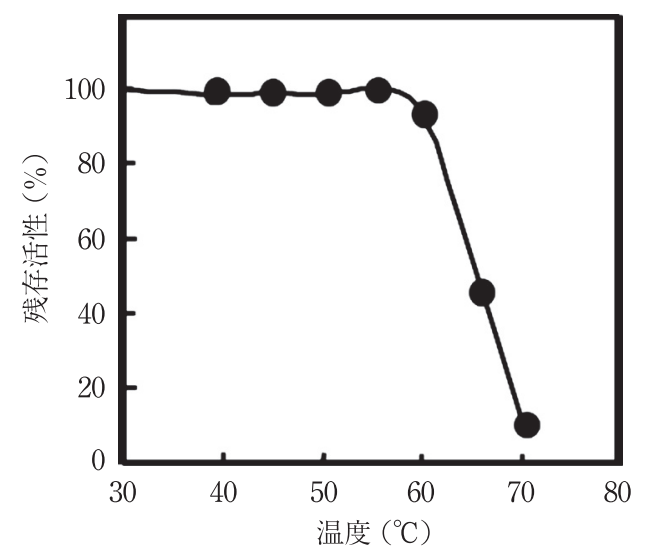

図 3 -A94株由来耐熱性アガラーゼの温度安定性

(各温度で 30 分間処理後の残存アガラーゼ活性)

$\mathrm{AgaO}$ の諸性質は大きく異なっていた.AgaA はアガ ロースを切断し主産物としてネオアガロオリゴ4糖を生 成する ${ }^{(2)}$. 一方, $\mathrm{AgaO}$ は主産物としてネオアガロオリ ゴ6糖を生成する ${ }^{(3)}$. AgaA は耐熱性を有する酵素であ

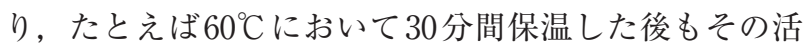
性を維持することができた（図3)。一方，AgaO は $50^{\circ} \mathrm{C}$ において 30 分間保温すると大きな活性低下が見られた。 金属塩に対する影響もこの両者の酵素では大きく異なっ た. AgaO は酵素の安定にカルシウムイオン $(10 \mathrm{mM}$ 程 度）あるいはマグネシウムイオン（100 mM 程度）を強 く要求する。あるいは $1 \mathrm{M}$ 程度の $\mathrm{NaCl}$ を添加すると安
定になる（興味深いことに海水に含まれる塩濃度に近 い).一方，AgaA はこれらの金属塩がなくても安定で あったＥDTAなどのキレート剤に対する効果も両者 で異なり,AgaA はキレート剤に耐性であった（安定化 や活性発現に2 価の金属イオンを必要としていないと言 える)。AgaAはSDSなどの界面活性剤に対する耐性も あり, 総体的にとても安定性の高い酵素であると言え る. 2009 年 4 月, AgaA は筆者らと試薬メーカーである ニッポンジーン(株)との共同開発により遺伝子解析用試 薬「耐熱性アガラーゼ」として製品化された。主にアガ ロースゲル電気泳動後の DNA 断片の抽出に利用される 試薬である（100 kbpを超える大きなサイズの DNA 断 片も効率良く回収できる)。アガロースゲルを融解状態 で保つための温度は高温（50 $\mathrm{C}$ 以上）である必要がある ため効率の良いアガロース分解に耐熱性アガラーゼが威 力を発揮する。さらに電気泳動用のアガロースゲルは通 常キレート剤であるEDTAを含有して扔り，本酵素は キレート剤にも耐性であることが長所として活かされて いる.

AgaA コードする遺伝子と AgaO をコードする遺伝 子はA94株の染色体上で約 $13 \mathrm{kbp}$ 離れて存在している ことがPCR実験より明らかとなった。両酵素遺伝子の 間には紅藻類多糖あるいは細胞壁成分を代謝するための 遺伝子群がクラスターを形成していることが予想できた ため，本 $13 \mathrm{kbp}$ 間とその前後の領域の DNA 配列解析を

表 1 - A94 株染色体DNA 上の $a g a A$ と $a g a O$ 遺伝子近傍に存在する ORF の解析

\begin{tabular}{|c|c|c|c|c|c|c|c|c|}
\hline $\begin{array}{l}\text { 遺伝 } \\
\text { 子名 }\end{array}$ & $\begin{array}{c}\text { 遺伝子 } \\
\text { コード位置 }\end{array}$ & $\begin{array}{l}\text { 転写 } \\
\text { 方向 }\end{array}$ & $\begin{array}{l}\text { アミノ } \\
\text { 酸数 }\end{array}$ & $\begin{array}{c}\text { 相同タンパク質の } \\
\text { アノテーション }\end{array}$ & $\begin{array}{c}\text { 相同タンパク質 } \\
\text { 保有株 }\end{array}$ & $\begin{array}{l}\text { 相同領域 } \\
\text { オーバー } \\
\text { ラップ }\end{array}$ & 相同性 & $\begin{array}{c}\text { アクセッション } \\
\text { 番号 }\end{array}$ \\
\hline orfl & $1900-3741$ & + & 613 & $\begin{array}{l}\text { Hypothetical protein } \\
\text { (containing a conserved- } \\
\text { domein for predicted } \\
\text { phosphatase, PhoX) }\end{array}$ & $\begin{array}{l}\text { Rhodospirillum rubrum } \\
\text { ATCC11170 }\end{array}$ & $285 / 590$ & 48 & YP_428088 \\
\hline $\operatorname{agaO}$ & $4306-7833$ & + & 1175 & Agarase (AgaO) & $\begin{array}{l}\text { Microbulbifer thermotolerans } \\
\text { JAMB-A94 }\end{array}$ & $1,175 / 1,175$ & 100 & BAD86832 \\
\hline $\operatorname{cgiA}$ & $8847-10556$ & + & 569 & l-Carrageenase & $\begin{array}{l}\text { Zobellia galactanivornas Dsij } \\
\text { DSM12802 }\end{array}$ & $185 / 569$ & 29 & CAC07822 \\
\hline orf 3 & $14581-15552$ & + & 323 & $\begin{array}{l}\text { 2-Keto-3-deoxygluconate } \\
\text { kinase }\end{array}$ & $\begin{array}{l}\text { Saccharophagus degradans } \\
2-40\end{array}$ & $143 / 316$ & 45 & YP_528128 \\
\hline $\operatorname{agaA}$ & 21118-22419 & + & 433 & Agarase (AgaA) & $\begin{array}{l}\text { Microbulbifer thermotolerans } \\
\text { JAMB-A94 }\end{array}$ & $433 / 433$ & 100 & BAD29947 \\
\hline orf4 & 1529-933 & - & 198 & Lipase class 2 & Cyanothece sp. PCC 8801 & $75 / 192$ & 39 & YP_002374003 \\
\hline orf5 & $14143-10634$ & - & 1169 & TonB-dependent receptor & $\begin{array}{l}\text { Saccharophagus degradans } \\
2-40\end{array}$ & $602 / 1,225$ & 49 & ABD81912 \\
\hline orf6 & $16411-15692$ & - & 239 & $\begin{array}{l}\text { Peptide transport system } \\
\text { permease protein }(\text { SapC })\end{array}$ & $\begin{array}{l}\text { Pseudoalteromonas atlantica } \\
\text { T6c }\end{array}$ & $105 / 235$ & 44 & YP_662115 \\
\hline orf7 & $17982-16429$ & - & 517 & Tryptophan halogenase & $\begin{array}{l}\text { Pseudoalteromonas atlantica } \\
\mathrm{T} 6 \mathrm{c}\end{array}$ & $332 / 517$ & 64 & YP_662116 \\
\hline orf8 & $20876-18072$ & - & 934 & TonB-dependent receptor & $\begin{array}{l}\text { Pseudoalteromonas atlantica } \\
\text { T6c }\end{array}$ & $547 / 932$ & 58 & YP_662117 \\
\hline
\end{tabular}


行った．その結果を表1に示す．2-ケト-3デオキシグル コン酸キナーゼなどいくつか興味深い遺伝子が見つか り, なかでもイオタカラギナーゼ遺伝子の発見は特に興 味深いものであった ${ }^{(4)}$. カラギーナンはアガロースと同 様に紅藻類に属する海藻（キリンサイなど）の細胞壁・ 細胞間に多く含まれる多糖であり，D-ガラクトースや 3,6-アンヒドロ-D-ガラクトースが $\alpha-1,3, \beta-1,4$ 結合で交互 につながった 2 糖を繰り返し単位とする直鎖状骨格を基 本骨格とする，さらにこの骨格に硫酸基が付与され，硫 酸化多糖として存在する.この硫酸基の付与形態の差で

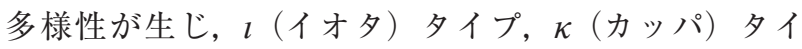

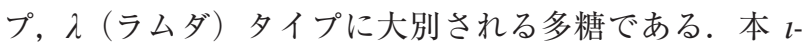
カラギナーゼ遺伝子を枯草菌宿主発現ベクター系 ${ }^{(5)} に$ 導入して生産させた䤉素の諸性質の解析を行った。 その 結果, 本酵素はエンド形式で $l$-カラギーナンを切断し, 最終産物としては 4 糖オリゴ糖を主産物として生成する 酵素であった. $\mathrm{NaCl}$ 濃度が $100 \mathrm{mM}$ 付近で活性が最大 となる. 反応過程での反応生成物の還元末端アノマー炭 素の立体配置を調べると本分解反応はインバージョン形 式で進行することが明らかとなった．本酵素は $l$ タイプ のカラギーナンを切断するが, $\kappa$ タイプ, $\lambda$ タイプのカ ラギーナンには全く作用しない厳密な基質特異性が認め られた。データベースを対象に既報告の酵素とアミノ酸 配列の相同性を調べた結果, Zobellia galactanivorans Dsij DSM 12802 由来の $l$-カラギナーゼと $29 \%, A l$ teromonas fortis ATCC 43554 由来の -カララギナーゼと 31\%の一致性を示した.さらに詳細にアミノ酸配列を比 較したところ, Rebuffetら ${ }^{(6)}$ が提唱した触媒残基 Glu245とAsp247の間には1個のアミノ酸残基しか存在 しないのに対し, A94株由来の $l$-カラギナーゼには7個 （Glu351-Asp359間）のアミノ酸残基が存在していた (図4)，通常，酵素全体の折り睍み構造が類似している 場合, 触媒を司るアミノ酸の立体配置は高く保存されて
いる.これを前提に, A. fortis 由来の酵素の構造を基に 触媒残基付近の立体構造を予想したが，A. fortis由来の 酵素とA94株由来酵素の活性残基と推定される酸性ア ミノ酸残基が重なり合うことはなかった。そこで活性中 心を形成することが予想される 2 つ酸性アミノ酸残基 を一つずつアミド型に変異させた $2 つ の$ 点変異酵素を作 成し，その活性や速度論定数を実際に測定した。その結 果，変異を施した 2 つの酸性アミノ酸残基のうちの一つ （Glu351）は，予想どおり酵素活性に必須であるという 結果が得られたが，もう一方 (Asp359) は必ずしも必須 ではないという結果が得られた. $l$-カラギーナンの $\beta-1,4$ 結合は，構成糖の一つである3,6-アンヒドロ-D-ガラク トースに存在する2-O-硫酸基による安定化を受けている ため，比較的安定と考えられる。しかしいったん， l-力 ラギーナンポリマーが $l$-カラギナーゼに結合した場合, 2-O-硫酸基は基質ポケットの中にある塩基性アミノ酸 （アルギニン）にしっかりと結合する．l-カラギーナン の $\beta-1,4$ 結合に対する安定化作用が失われ, 結合は不安 定になる，本来安定なはずの構成糖間の結合が，酵素と の相互作用によって弱められることによって，切断が容 易になると推定することができる．活性アミノ酸残基が 必ずしも2つそろわなくとも, 基質の加水分解が起こり 得るという非常に珍しい現象は, 酵素が引き起こす基質 の変化により説明することができると考えている.

\section{3 種のカラギナーゼの取得とその応用展開}

ヒト細胞の表面には，グリコサミノグリカンと呼ばれ る硫酸化糖が存在しており, 細菌やウィルスの認識など 生命にとって重要な役割を果たしていることが知られて いる. カラギーナンは前項でも記述したと扔り, 硫酸化 多糖であり, それらの構造はヒ卜細胞表面糖鎖とも類似 性があり，新たな生理機能活性の発見が期待できる。し

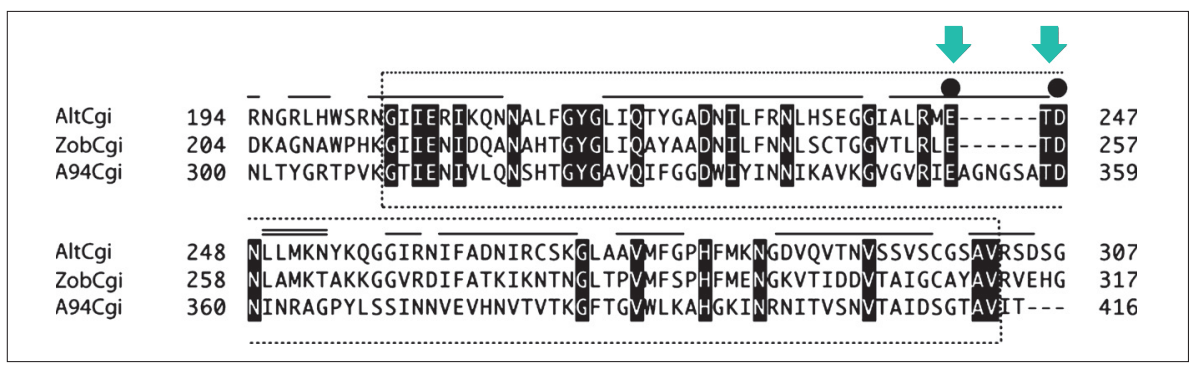

図 4 - -カラギナーゼ活性中心付近アミノ酸配列のアライメント

AltCgi : Alteromonas fortis ATCC 43554 由来の $l$-カラギナーゼ. ZobCgi : Zobellia galactanivorans Dsij DSM 12802 由来の $l$-カラギナーゼ. A94Cgi : Microbulbifer thermotolerans A94由来のl-カラギナーゼ. (矢印部分はRebuffetらが提唱した触媒残基, 破線内は3種の酵素配列 において高い保存性が認められた領域を示す.) 


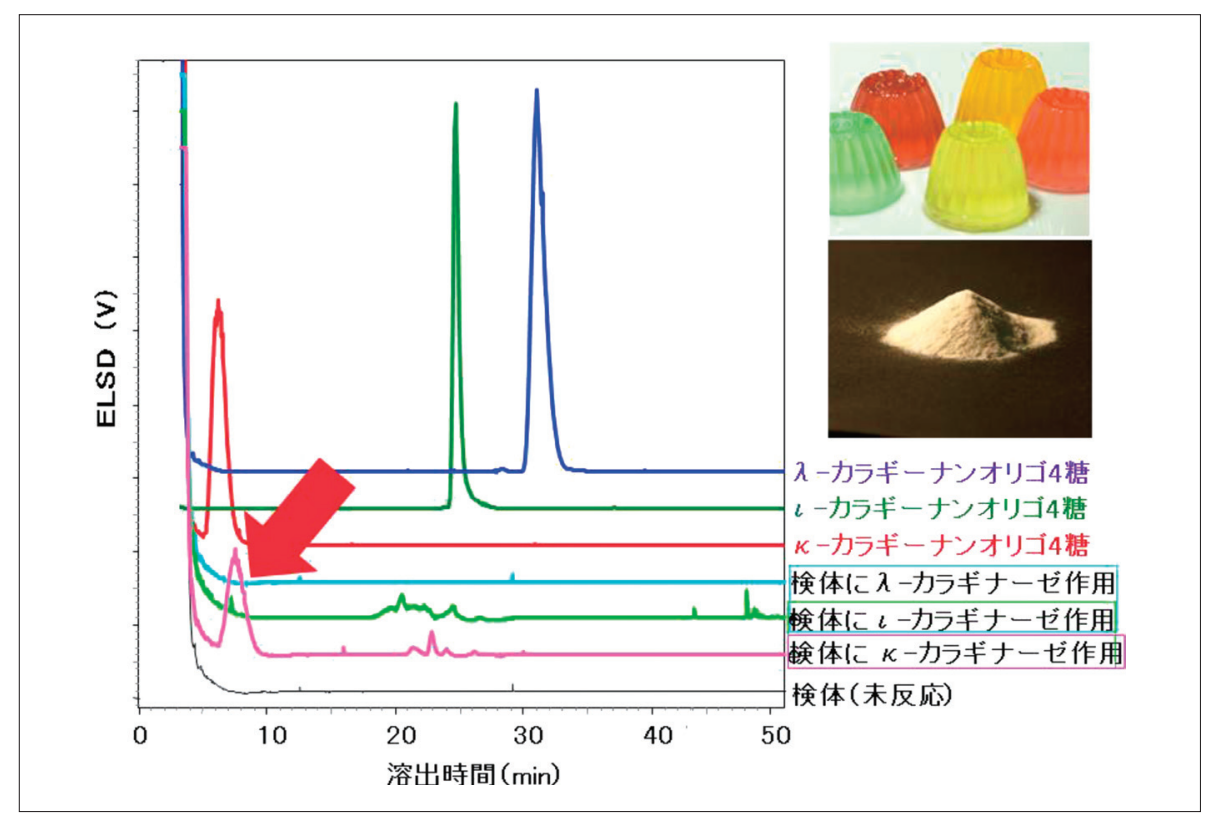

図 5 -3種カラギナーゼを用いた食 品・飲料品中のカラギーナン種別同 定

食品・领料品素材に対して $l-k, \lambda$ - $\lambda$-カ ラギナーゼを各々作用させた後ス夕 ンダードを参照にHPLC分析（陰イ オン交換カラム使用）を行う。図内 の矢印は検体に $\kappa$-カラギナーゼを作 用させた際に得られたピークが $\kappa$-カ ラギーナンオリゴ4糖と一致した結 果を示す。
かしながら多糖のままでは分子が大きいためヒト細胞に 対する機能評価が容易ではない，そこでカラギーナンを オリゴ糖サイズに切断する酵素を樑海微生物から取得す ることとした，探索の結果Pseudoalteromonas 属細菌か ら $\lambda$-カラギーナン切断酵素遺伝子の取得に成功した ${ }^{(7)}$. 驚くことに本醅素はデータベースに登録されている既報 告の酵素と全く相同性を示さなかった。 新規酵素として 国際生化学分子生物学連合に認められ, 新たな EC 番号 （EC 3.2.1.162） が設定された。 $\kappa$-カラギーナン切断酵素 もPseudoalteromonas属細菌より発見した。 $\kappa, l-\lambda$-カラ ギーナン分解酵素の 3 種酵素を深海微生物より発見する ことがなしえたので, 現在, 各カラギーナンをオリゴ糖 サイズに消化し，ヒト細胞に対してその生理機能活性を 調べている. 3種カラギナーゼのほかの応用研究として 食品・飲料品に含まれるカラギーナンの種別同定を提案 した．3種の酵素の基質特異性を調べたところ明確な基 質特異性が確認できた。 A94株由来 1 -カラギナーゼの項 でも記述したのと同様に, $\lambda$-カラギナーゼは $\lambda$ タイプの カラギーナンをよく分解するが他タイプのカラギーナン には作用しない， $\kappa$ タイプに関しても全く同様であっ た。この厳密な基質特異性を利用することで混合物中に 含まれるカラギーナンの種別を解析することが可能で あった。そこで，これら 3 種の酵素を応用した，食品・ 飲料品素材中に含まれるカラギーナンの簡易同定法（図 5）を提案した ${ }^{(8)}$.

\section{海底より検出されたリグニン代謝微生物}

深海は光合成による一次生産が行われないため多くの 場所では生物にとって栄養となる有機物がそしい。一 方，陸上や浅海域で増殖した植物や動物の死骸が沈降し た場所では，沈降物を大量かつ持続的な栄養源として， 多様で活動的な生態系が形成される。筆者らは深海に沈 降した有機物を中心に形成される生態系に棲息する生物 には，バイオマスをさまざまな物質やエネルギーに変換 する優れた能力があると考えており，これらの生物機能 を見いだし，われわれの生活に活用するための取り組み を行っている. 地球で生産されるバイオマスのうち最も 存在量が多いのはセルロースであり, リグニンが2番目 に続く.リグニンは芳香族化合物であるフェニルプロパ ノイドが不規則に結合した非常に複雑な構造をしてお り, 極めて難分解性であるため, その利用技術開発は, 現在も極めてチャレンジングな課題として残されてい る. 近年, リグニンの構造や化学的性質から石油化学製 品の代替として利用できる可能性が注目され始め, 非常 に精力的な研究が進んでおり, 物理化学的, 生物学的手 法を用いたリグニン変換に関する分子基盤についてさま ざまな知見が急速に集積しつつある ${ }^{(9,10)}$.

地上での木材の生物による分解は木材腐朽菌と総称さ れる真菌類の作用によって開始される。木材腐朽菌は酸 化還元酥素や低分子化合物を生産し，これらを協調的に 制御したさまざまな菌体外ラジカル反応により, 高密度 にパッキングされた高分子セルロースやリグニンを巧み に分解していく，腐朽菌による腐朽が進んだ木材は，通 

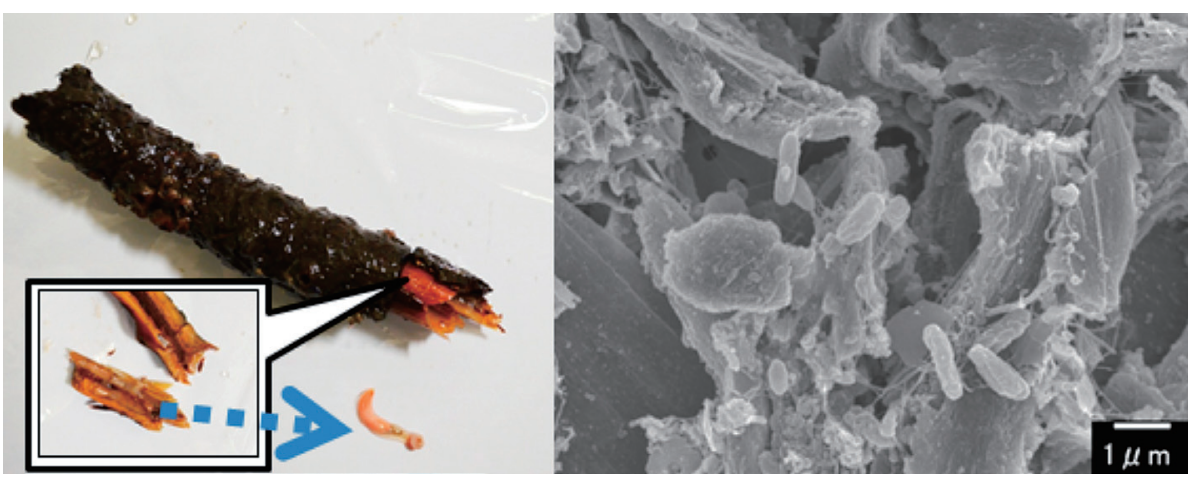

図 6 ・海底から取得された枕木とそ の内部から検出された穿孔性の貝 (左)および穿孔する際に形成される 細粒子フンの表面に検出された微生 物の電顕写真(右)
常強い酸性を示すため, 耐酸性バクテリアコミュニ ティーが同時に形成されることも知られている(11)。一 方, 海洋中では, 多くの木材腐朽菌の増殖は阻害され, 木材腐朽菌酵素の多くもまた, 海水中で阻害されること が知られている。一般に海域に入ってきた木材の場合に は，キクイ貝やフナクイムシと呼ばれる二枚貝による穿 孔で分解が開始されることが多い (図6左写真).木材 を飭とする貝が穿孔する際には細かい粒子のフンが周辺 に放出され, 種々の微生物に生活の場や栄養を提供する (図6右写真)。貝を捕食するゴカイの仲間も集まり，活 動的なコミュニティーが形成される。生物密度が高ま り, 硫化水素の発生を伴う場合もしばしば観察される. このような特殊な生態系には，陸上とは別の木材成分分 解機構が存在する可能性が期待できる。 そこで筆者らは 木材バイオマス成分の一つとして，まずリグニン代謝の 下流に位置する芳香族化合物を代謝する微生物の探索を 行った ${ }^{(12)}$. 海水にオガクズを混ぜ作った培地を使って, 深海沈木や海底堆積物などから約 500 株の微生物を単離 し，これらの微生物の芳香族化合物に対する代謝活性を 調べたところ, 多くの微生物がクマル酸, フェルラ酸, バニリンなどの複数のリグニン関連芳香族化合物を代謝 することがわかった．代謝株の $16 \mathrm{~S}$ rRNA遺伝子に基づ く分類学的位置を調べたところ, Firmicutes, Actinobacteria, Bacteroidetes, Proteobacteria などの多様な門 に属していた. 現在, これらの微生物の代謝様式や遺伝 子の解析を進めている。これらの深海微生物から, リグ ニンあるいはリグニンから誘導される低分子化合物の生 物変換に役立つ機能を特定し，プラスチックなど，身近 な生活に必要な化成品に変換する技術へとつなげていき たい.

\section{おわりに}

深海には化学合成環境など一次生産が盛んな場所も散 在するが, 大半の深海領域に棲息する微生物は上層部か
ら沈んでくる限られた有機物に栄養源を依存している. ゆえに効率の良い特別なアイテム（生体触媒）を獲得 （進化）し，したたかに暮らしている微生物も多いと推 察される。筆者らは上記のほかにも $\alpha$ アガラーゼ ${ }^{(13)}$, 酸化剂耐性アミラーゼ ${ }^{(14)}$, 糖転移酵素（難水溶性化学 物質の可溶性を向上) ${ }^{(15)}$, トレハロース生成酵素, 強力 溶菌酵素などの有用酵素のほか, 新規性のたいへん高い 深海微生物のいくつから抗菌活性物質の発見にも成功し ている。またこれらの報告はいずれかの機会に紹介させ ていただきたい。

\section{文献}

1) M. Miyazaki et al. : Int. J. Syst. Evol. Microbiol., 58, 1128 (2008).

2) Y. Ohta et al.:Biosci. Biotechno.l Biochem., 68, 1073 (2004).

3) Y. Ohta et al.:Appl. Microbiol. Biotechnol., 66, 266 (2004).

4) Y. Hatada et al. : Mar. Biotechnol., 13, 411 (2011).

5) Y. Hatada et al. :J. Agric. Food Chem., 54, 9895 (2006).

6) E. Rebuffet et al. : Biochemistry, 49, 7590 (2010).

7) Y. Ohta \& Y. Hatada:J. Biochem., 140, 475 (2006).

8）秦田勇二, 大田ゆかり：財団法人アサヒビール学術振興 財団研究紀要, 22, 23 (2009).

9）飯塚堯介監修：“ウッドケミカルスの新展開”，シーエム シー出版, 2007.

10) D. Floudas et al. : Science, 336, 1715 (2012).

11) V. Valásková et al. : ISME J., 3, 1218 (2009).

12) Y. Ohta et al.: OJMS, 2, 177 (2012).

13) Y. Ohta et al. : Curr. Microbiol., 50, 212 (2005).

14) Y. Hatada et al. : Enz. Microbial. Tech., 39, 1333 (2006).

15) V. S. Hung et al. : Appl. Microbiol. Biotechnol., 68, 757 (2005). 
プロフィル

秦田 勇二 (Yuji HATADA)

$<$ 略歴 $>$ 現在, 海洋研究開発機構・海洋極限環境生物圈領域・海 洋生物多様性研究プログラム・海洋有用物質の探索と生産システ ムの開発研究チーム・チームリーダー, 横浜市立大学大学院生命 ナノシステム科学研究科客員教授 (兼務)

宮崎 征行（Masayuki MIYAZAKI）＜略歴>現在, 海洋研究 開発機構・海洋極限環境生物圈領域・深海地殼内生物圈研究プロ グラム・深海地殼内生命圏システム研究チーム・技術研究副主事
大田ゆかり（Yukari OHTA）

$<$ 略歴 $>$ 現在, 海洋研究開発機構・海洋極限環境生物圈領域・海 洋生物多様性研究プログラム・海洋有用物質の探索と生産システ ムの開発研究チーム・主任研究員

竹山 春子 (Haruko TAKEYAMA)

<略歴>1992 年東京農工大学工学研究科物質生物工学専攻博士後 期課程修了, 博士 (工学) /マイアミ大学博士研究員 / 1994 年よ り東京農工大学工学部生命工学科 (助手, 准教授, 教授) $/ 2007$ 年より早稲田大学先進理工学部生命医科学科教授<研究テーマと 抱負>環境生物遺伝子資源の解析と有効活用，それらを支える解 析技術の開発. 難培養微生物学の扉を開くことを目指しています <趣味>庭いじり 